\title{
Lyme-borreliose - tid for et navneskifte?
}

\author{
Sykdom etter infeksjon med bakterien Borrelia burgdorferi heter på amerikansk/engelsk «Lyme disease», \\ alternativt omtalt som det mer passende «Lyme borreliosis». På norsk kalles sykdommen ofte «Lyme- \\ borreliose».
}

Navnet stammer fra en lokal epidemi av sykdom blant barn i byen Lyme i Connecticut på østkysten av USA i 1975 (1). I Lyme ble det rapportert om sammenheng mellom flåttbitt, et spesielt, ringformet hudutslett (erythema migrans) og et klinisk bilde med nedsatt allmenntilstand og leddlidelser hos barn.

Muntlig er det vanlig å kutte ut «Lyme» og bare si «borreliose». Dette er et mer presist og enkelt uttrykk for en borreliainfeksjon. «Lyme» er bare en historisk nisse på lasset som det nå kan være på tide å bli kvitt, i hvert fall på norsk. Vi snakker om en borreliainfeksjon, og «Lyme» brukes ikke språklig sett for å skille infeksjonen fra noen annen type borreliose.

Selv bruker jeg systematisk «borreliose» i min bok om flåttoverførte sykdommer (2). I Tidsskriftet har jeg tidligere sett «Lyme- borreliose», og jeg anser språknormen her for å være retningsgivende for norsk medisinsk skriftspråk. Hadde det ikke vært på sin plass at Tidsskriftet heretter begynte å forenkle «Lyme-borreliose» til «borreliose» for å få satt en bedre standard for norsk medisinsk språkbruk?

En mulig ulempe ved et eventuelt navneskifte er at ordet «Lyme» også brukes om en del av de sykdommene borreliainfeksjon kan gi, for eksempel «Lyme-meningitt», «Lyme-artritt» og «Lyme-nevroborreliose». Dette burde enkelt kunne løses. For «Lymenevroborreliose» klarer vi oss uansett best uten «Lyme», tilsvarende som for «Lymeborreliose». De to andre sykdommene kan man forslagsvis omskrive med for eksempel «borreliaindusert meningitt» og «borreliaindusert artritt».

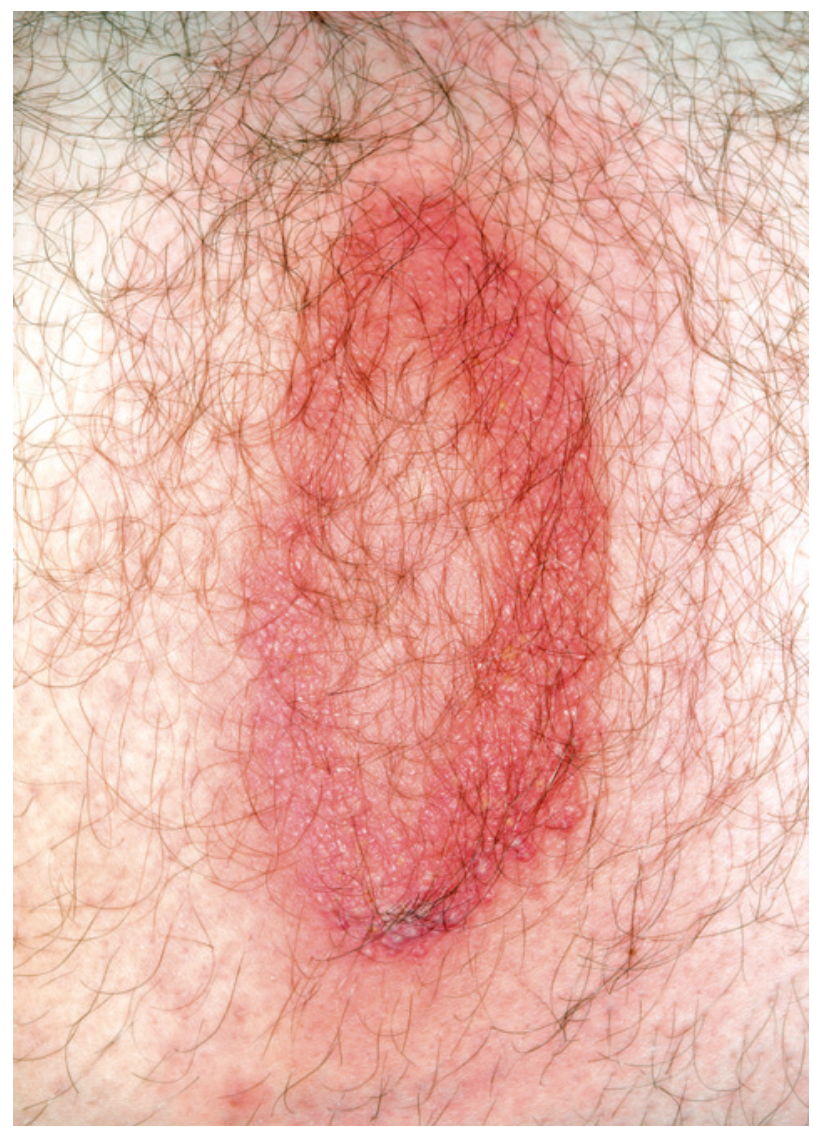

La meg avslutningsvis problematisere om det faktisk er slik at sykdommen kalles «Lyme-borreliose» på norsk. Et Google-søk gir for eksempel snaut 19000 treff på norske sider for «Lyme-borreliose», mens tilsvarende søk for «borreliose» gir ca. 60000 treff. Om vi fra sistnevnte trekker fra de 19000 som har både «Lyme» og «borreliose», sitter vi igjen med 40000 norske treff på borreliose uten Lyme.

På søkesiden Retriever, som søker gjennom de fleste norske aviser, gir «borreliose» over 3600 treff, mens «Lyme-borreliose» gir snaut 1400 treff. Treffene i Retriever indikerer hvordan særlig journalister omtaler sykdommen. «Borreliose» er allerede over dobbelt så vanlig i bruk som «Lyme-borreliose» både på norske nettsteder og i norske aviser. Store norske leksikon bruker «borreliose», og i oppslaget nevnes ikke engang «Lyme». Dette er nok en grunn for Tidsskriftet til å omtale sykdommen som kun «borreliose». Da kan vi fremskynde prosessen med å bli kvitt «Lyme».

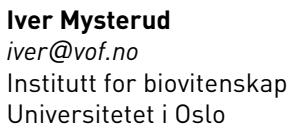

Iver Mysterud (f. 1966) er dr.philos. i biologi, med en avhandling om evolusjon og mennesket. Han er fagredaktør i Helsemagasinet vitenskap og fornuft (VOF). Han har nylig gitt ut en bok om flåttoverførte sykdommer.

\footnotetext{
Litteratur

1. Steere AC, Malawista SE, Snydman DR et al. Lyme arthritis: an epidemic of oligoarticular arthritis in children and adults in three connecticut communities. Arthritis Rheum 1977; 20: 7-17.

2. Mysterud I. Et alvorlig helseproblem: flåttoverførte sykdommer. Bærum: Stiftelsen vitenskap og fornuft, 2014.
}

Mottatt 13.5. 2014, første revisjon innsendt 18.6. 2014, godkjent 5.8. 2014. Redaktør: Marit Skaar Fjellhaug. 